Florida International University FIU Digital Commons

3-18-1980

\title{
A study to determine whether the needs of the physically handicapped are being met by the hotels in the city of Miami Beach, Florida
}

Judith A. Casey

Florida International University

DOI: $10.25148 /$ etd.FI14052597

Follow this and additional works at: https://digitalcommons.fiu.edu/etd

Part of the Hospitality Administration and Management Commons

\section{Recommended Citation}

Casey, Judith A., "A study to determine whether the needs of the physically handicapped are being met by the hotels in the city of Miami Beach, Florida" (1980). FIU Electronic Theses and Dissertations. 2025.

https://digitalcommons.fiu.edu/etd/2025 


\section{ABSTRACT}

A STUDY TO DETERMINE WHETHER THE NEEDS OF THE PHYSICALLY HANDICAPPED ARE BEING MET BY THE HOTELS IN THE CITY OF MIAMI BEACH, FLORIDA by Judith A. Casey

The purpose of this study was to determine whether the needs of the physically handicapped traveler are being met by the hotels in the City of Miami Beach, Florida. A sample was drawn from the hotel population. Mail questionnaires and personal interviews were used as the methods for collecting the data from the sample. The data was compiled and a hotel mean was computed. A mean was also calculated from the standards recommended by the American National Standards Institute to the American Hotel and Motel Association. The statistical test, The Significance of Difference Between Two Means, was used to test the hypothesis. A significance of difference was found and the hypothesis: The hotels in the City of Miami Beach, Florida, are not meeting the needs of the physically handicapped traveler, was accepted. 
A STUDY TO DETERMINE WHETHER THE NEEDS OF THE PHYSICALLY HANDICAPPED ARE BEING MET BY

THE HOTELS IN THE CITY OF

MIAMI BEACH, FLORIDA

by

Judith A. Casey

A hospitality project submitted in partial fulfillment of the requirements for the degree of MASTER OF SCIENCE

in

HOTEL AND FOOD SERVICE MANAGEMENT

at

FLORIDA INTERNATIONAL UNIVERSITY

Committee in charge:

Professor William J. Morgan, Ph.D.

Chairperson

Associate Professor Fritz G. Hagenmeyer

March 1980 
To Professors Morgan and Hagenmeyer

This hospitality project, having been approved in respect to form and mechanical execution, is referred to you for judgment upon its substantial merit.

Dean Gerald W. Lattin

School of Hospitality Management

The hospitality project of Judith A. Casey is approved.

Associate Professor

Major Professor

Date of Examination:

3 jir|ro 


\section{A STUDY TO DETERMINE WHETHER THE NEEDS OF THE PHYSICALLY HANDICAPPED ARE BEING MET BY THE HOTELS IN THE CITY OF MIAMI BEACH, FLORIDA}

by

Judith A. Casey

A hospitality project submitted in partial fulfillment of the requirements for the degree of

MASTER OF SCIENCE

in

HOTEL AND FOOD SERVICE MANAGEMENT

at

FLORIDA INTERNATIONAL UNIVERSITY 


\section{ACKNOWLEDGEMENTS}

This writer wishes to express her personal appreciation to Professors William J. Morgan and Fritz Hagenmeyer, School of Hospitality Management, Florida International University, for their guidance and encouragement through this study. A special thanks to Dr. Morgan for acting as Chairperson and offering positive advice and constructive criticism.

A special appreciation to my father and mother for the encouragement to continue my education and the support they provided throughout this study. 
TABLE OF CONTENTS

I. THE NATURE AND SCOPE OF THE STUDY 1

Untapped Market 1

Nature of the Study 4

Scope of the Study 7

II. THE REVIEW OF THE LITERATURE 10

$\begin{array}{ll}\text { Historical Overview } & 10\end{array}$

Who Are the Handicapped? 13

The Handicapped Traveler 16

Man-made Environmental Barriers 18

$\begin{array}{ll}\text { Psychological Barriers } & 19\end{array}$

Architecture Barriers 21

$\begin{array}{lll}\text { III. DESIGN OF THE STUDY } & 26\end{array}$

Sample Selection $\quad 26$

Collection of the Data 28

Data Analysis $\quad 30$

Method of Measurement 31 
TABLE OF CONTENTS (Continued)

IV. FINDINGS AND DISCUSSION 32

Questionnaire Response 32

Problems 33

Findings $\quad 34$

Conclusions and Recommendation 38

V. APPENDICES

A. Sample of Hotel Questionnaire 41

B. Sample of Cover Letter 44

C. Sample of Questionnaire for the Handicapped 45

$\begin{array}{ll}\text { LIST OF REFERENCES } & 47\end{array}$ 


\section{CHAPTER I}

THE NATURE AND SCOPE OF THE STUDY

An Untapped Market

It is estimated that approximately one out of every ten Americans are handicapped; in other words, they have some form of physical or mental impairment which limits their mobility within our environment. Advances in medical care and rehabilitation procedures have saved many lives, and because of these advances, the number of handicapped people is steadily increasing. ${ }^{1}$ These individuals constitute a sizable potential market for all kinds of products and services. Historically, the Hospitality Industry has ignored this market. In short, they, among many others, have actively excluded this substantial market segment. It seems unthinkable that the Hospitality Industry wouldn't have been one of the first to understand and cater to the needs of the handicapped, since it's their ancient and honorable tradition to serve the public. ${ }^{2}$ However, society as well as the Hospitality Industry has erected and maintained barriers to these people throughout history.

1"Hotels and Motels and the Handicapped," Hotel and Motel Management, January 1973 , p. 25.

${ }^{2}$ Louis Weiss, Access To The World: A Travel Guide For The Handicapped (New York: Chatham Square Press), p. 97 . 
In the last few years, an increased public awareness and federal legislation have made day-to-day living easier for the physically handicapped. A 1961 document, ANSI Standard 117.1, which included the specifications for making buildings and facilities accessible to the physically handicapped had considerable influence on federal legislation. This legislation included the Architectural Barrier Act in 1968 which selected these standards to be applicable to all buildings used by the public. Other legislation passed was the Rehabilitation Act in 1973 and the Bill of Rights for the Handicapped in $1977 .^{3}$ Through this legislation, the handicapped have gained unprecedented civil rights in education, health and social services. It has also provided voting rights, employment security, housing and transportation privileges. 4 The handicapped themselves have refused to remain in the background. They want to take their place in society and participate in a broader range of activities. One of these activities includes the right to trave1. The handicapped are psychologically, physically and financially equipped to travel. 5

As a result of this encouraging equitable treatment, approximately thirty-six million physically handicapped

${ }^{3}$ David Morton, "Bearing Down on Barriers," Progressive Architecture, April 1978, p. 63. p. 227 .

${ }^{4}$ Lil1y Bruck, Access (New York: Random House, 1978), ${ }^{5}$ Weiss, Access To The World, p. xii. 
individuals have been established as a market. ${ }^{6}$ Thirtysix million individuals is a sizable market, but add to that the families and friends who might accompany them when traveling, and the figure becomes a huge and largely untapped market. Families with handicapped members, handicapped business men and women, organizations of handicapped or those serving the handicapped look for vacation and convention facilities where handicapped guests will not be restricted because of lack of proper facilities. 7 Therefore, the time is here that hotels must become aware of the special needs of these people to achieve full integration of the handicapped into the mainstream of society. 8

Are hotels aware of this sizable market? Some hotels have become conscious of this untapped market and surprisingly are offering facilities for the handicapped traveler. This awareness has led to an increase of hotel rooms for the handicapped throughout the nation. However, it is necessary to book reservations well in advance because there is still a limited number of accessible rooms. Realistically, the handicapped person has to carefully choose the American city to visit and then plan the hotel to stay in and the things to do and see. ${ }^{9}$

${ }^{6}$ Bruck, Access, p. xvii.

${ }^{7}$ Hotel and Motel Management, p. 25.

${ }^{8}$ Pamela Hoye, "Teaching Others About Disability," Disabled U.S.A., Vol. 2, No. 2, 1978 , p. 14.

9"Travel Tips for the Handicapped," Consumers Guide to Travel Information, 1978 . 
Hotels can benefit from recognizing the physically handicapped as a potential market for both economic and humanitarian reasons. 10 The hotel's architectural, attitudinal and admission barriers have hindered the handicapped person from his right to travel. (See Scope of Study for definitions.) Therefore, consideration must be made to meet their needs and hotels must welcome them as a traveling guest.

Nature of the Study

Handicapped people are coming out of their shells and demanding equal treatment to move freely within the society. Leisure activities can help them achieve as much freedom and mobility as possible so they can lead the freest, most independent lives of which they are capable. ${ }^{11}$ Handicapped people need to participate in these leisure activities. Travel has been one of these activities which has given the handicapped person a more healthy outlook and a more interesting life. This paper is concerned with whether the hotels are meeting the needs of the physically handicapped traveler.

Accessibility for handicapped persons is becoming more commonplace. For example, in 1973, ITT Sheraton Corporation of America instituted a new policy, whereby, all handicapped guests receive VIP treatment in all

${ }^{10}$ Edward Brodsky-Porges, "Welcoming The Handicapped Traveler," The Cornell H.R.A. Quarterly, November 1978, p. 6 .

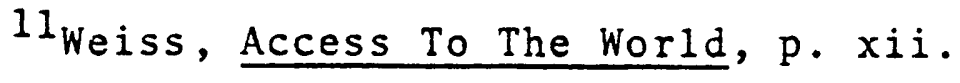


Sheraton Hotels. Today, new Sheraton hotels will have $5 \%$ of their rooms accessible to people in wheelchairs. Their existing properties are installing ramps and making available special tables. Braille menus are also available in all Sheraton properties. 12

Ramada Inns began to include rooms equipped for the handicapped as far back as 1965. Currently, they have 455 rooms especially equipped for the handicapped guest. In its standards for the newly built or remodeled Ramada Inns, the company requires:

a minimum of two wheelchair guest rooms close to the restaurant and exterior exits, with 36 inch wide outside doors and ample bedroom space for maneuvering a wheelchair. Required for public bathroom areas are outward-opening doors on stalls, towel and spąp dispensers no more than 40" above the ground. 13

Many hotel chains require all new or remodeled properties to have at least one or two rooms accessible to the handicapped person. But this researcher found that each chain has its own definition of accessibility. Some hotels feel accessibility is a room on the first floor with wide doors at the entrance and the bathroom. Yet other hotel chains feel accessibility is a room that has been specially equipped and designed for the physically handicapped.

12"Accommodate The Handicapped," Moteletter, Washington: Motel Services, Inc., March $197 \overline{8 .}$

13 Marcia Wallace, "Ready for the Handicapped," Trave 1 and Leisure, April 1978, p. 38. 
It does appear that the entire industry is trying to make an effort to improve a bad situation. Nevertheless, architectural, attitudinal, and admission barriers deny millions of handicapped citizens their right to travel. This is seen in a recent survey made by the magazine, Progressive Architecture.

In most public transportation, places of entertainment, restaurants, and hotels, there is no or inadequate accommodation for the handicapped. There seems to be little awareness or concern that $36 \mathrm{mil}$ lion Americans are denied many of the ordinary things of 1 ife that are available to anyone else. When Progressive Architecture, for instance, recently telephoned 14 of the largest New York hotels to ask if those in wheelchairs could gain access to their public spaces, only six could answer affirmatively. Of the remaining eight, some said access was not possible and some did not know whether or not it was. When the question was pursued further, to ask if wheelchairs could fit through guest room doors and bathroom doors, only one could answer positively; the others said no or did not know. 14

In addition to these architectural barriers, the

hotels have psychological barriers which preclude them from getting business from the physically handicapped. A severely handicapped individual discusses his actual experience of this barrier when dining out.

One of the barriers to pleasant mealtimes for severely handicapped persons can be attitudes of the people with them and around them. There are very few people that understand what a complicated procedure a mealtime is for a handicapped person like myself. It is nice to go out to a restaurant, but an experience like this one is so strained that it's likely to be memorable all right, but for all the wrong reasons. 15

${ }^{14}$ David Morton, Progressive Architecture, p. 63.

${ }^{15}$ Andrew Clifton and Barbara McLean, editors, Mealtime For Severely and Profoundly Handicapped Persons (Baitimore: University Park Press, 1977), p. 14. 
Scope of the Study

In order to stimulate an awareness of the problems faced by the handicapped, this researcher will test the following Hypothesis: The hotels in the city of Miami Beach, Florida, are not meeting the needs of the physically handicapped traveler.

For the purpose of this study, the following definitions are significant.

Physically handicapped person. An individual who is prevented from attaining his maximum functional level because of environmental constraints. 16

Disabled person. An individual who has a physical or mental impairment which limits a person's life activities. 17

Architectural barrier. A design or structure that tends to restrict movement of a physically handicapped person. 18

Psychological barrier. A mental attitude in the minds of people that tends to separate people from mingling. 19

The words hotel or motel will be used interchangeably in the study, except where specifically noted.

Variables involved in the study are:

(a) Independent: The hotels located in Miami Beach, Florida.

${ }^{16} \mathrm{John}$ H. Catlin and Michael A. Jones, "Design for Access," Progressive Architecture, p. 66.

17 Ibid., p. 66.

$18_{\text {Bruck, Access, p. } 20 .}$

${ }^{19}$ Roberts Nelson, Creating Community Acceptance For Handicapped People (Springfield: Bannerstone House, 1978), p. 18. 
(b) Dependent: The amount and type of services and facilities offered a physically handicapped guest.

The American National Standards Institute has recommended handicapped standards to the American Hotel and Motel Association. These standards will be used by this researcher as a tool to evaluate whether the hotels are meeting the needs of the handicapped guest. A sample of hotels will be selected from the total population through a method of systematic sampling. Data will be obtained from these hotels through a questionnaire. This will include information on the facilities available to the physically handicapped and the training given their hotel employees on the needs and services of the handicapped. The information from this questionnaire will be used to determine a hotel mean. The recommended standards will be weighted and a mean determined. From this statistical information the Significance of the Difference Between Two Means will be used to test the hypothesis. This test will determine whether there is any significant differences between them or whether the difference is due to chance. This statistical test will determine if the hypothesis of the study can be accepted or rejected.

This researcher expects to find that the hotels in the city of Miami Beach are not meeting the needs of the physically handicapped traveler. The hotel manager will be aware of the handicapped market and also aware that his 
hotel facilities restrict the mobility of the handicapped. The hotels will need to be renovated to meet these needs and it will not only take time and effort, but a great deal of money. In 1977, the Internal Revenue Service began to allow the lodging business a tax incentive for removing architectural barriers. A business can deduct up to $\$ 25,000$ per year for barrier removal. 20 However, the researcher expects to find that the owners are not willing to make such a change. Their rational will be that there just isn't sufficient demand for such costly changes or other hotels offer these facilities for such guests.

There are more than 36 million handicapped people and all too often they are denied access to hotels because of architectural barriers or discriminated against because of psychological barriers. Therefore, the purpose of this study is to generate an awareness of the difficulties confronted by handicapped people when traveling. Many hotels are simply unfamiliar with or insensitive to these difficulties.

Hotels should begin to make every effort to increase their share of the handicapped market. This researcher would like to see the hotels develop attitudes and facilities whereby handicapped travelers could fit into the mainstream of any travel situation. The mainstreaming of handicapped people would provide them the equal opportunity to travel.

${ }^{20}$ Muriel Horton and Deborah Scheckter, "Tax Incentives for Business Women and Men," Disabled U.S.A., Vol. 1, No. 7 , 1978 . 
CHAPTER I I

THE REVIEW OF THE RELATED LITERATURE

This chapter will discuss the views and significant findings of researchers, educators, psychologists and the handicapped themselves. Through their research efforts, this writer was able to add perspective and meaning to this study. In the next few pages, this chapter will give a historical overview of the handicapped person's effort to join the main stream of society and the man-made barriers they encounter when traveling.

Historical Overview

In the early years, handicapped people were thought of as not real people. They were made to adapt totally to society but society had no intention of adapting to them. Individuals with handicaps were all too often excluded from schools, barred from employment, denied access to transportation, buildings and housing, and discriminated against by archaic laws and attitudes. 21

In the 1950's, there was a growing movement which forced society to at least begin to adapt to its handicapped citizens. This movement began with informal groups after

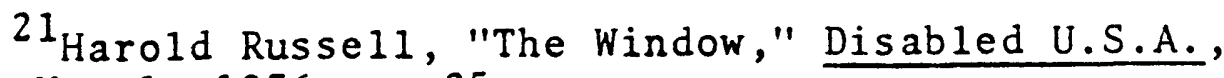
Vo1. 1, No. 1, 1976, p. 25 . 
World War II. 22 During World War II, professional people were drafted into war, and consequently, many were injured and returned home with handicaps. They found themselves unable to resume a normal life because of the architectural barriers they faced at their place of work. At this time, these informal groups began to apply pressure to legislation in the areas of job opportunities, transportation and accessibility. Gradually, architectural and transportation barriers began to crumble and adaptations were made in the workplaces for the handicapped. Then, in the sixties and early seventies, handicapped people began to assert themselves through the political system. They began to insist on their rights as handicapped people. At that time, a great deal of legislation was enacted by Federal and State governments to insure legal rights and beneficial services to the handicapped individual. 23

Federal legislation passed the Architectural Barrier Act of 1968. This 1 aw requires all new or renovated public buildings, wholly or partially financed by Federal funds, to be accessible to the handicapped. However, compliance was voluntary, but in 1973 it was made mandatory by the Rehabilitation Act. There are three sections in this Act that made this law perhaps the most significant landmark to date in the struggle of the handicapped. 1978 , p. 31 .

\section{2 "News Report," Progressive Architecture, April}

${ }^{23}$ Russe11, Disabled U.S.A., p. 25. 
Section 502 established a board to enforce compliance with the Act, Section 503 covers the hiring of a qualified handicapped person who can perform the job with reasonable accommodations, and Section 504 stipulates that programs or activities funded by or dealing with the federal government must be accessible to the handicapped. The drawback of such anti-barrier legislation is that it usually covers only publicly funded buildings. Although, many of the buildings used for daily routine services are open to the public, they are usually not built with public funds. These buildings are often not covered by such legislation. 24

In June, 1977, the Bill of Rights for the Handicapped was signed, making this date a landmark in the quest for equal treatment inaugurating a new era of civil rights for the handicapped. One right included in this legislation was the entitlement of every handicapped child a free education in the public school system. 25

Every citizen has certain fundamental rights. Among those rights is the one to move freely within society. Handicapped citizens can not be denied this right merely because they are handicapped. 26

24 Catlen and Jones, Progressive Architecture, p. 64. 25 Bruck, Access, p. 6. 26 Ibid., p. 5 . 
Who Are The Handicapped?

The first attempt to identify America's handicapped citizens was in the 1970 Federal census. At that time, it was found that approximately $10 \%$ of all Americans are physically handicapped. 27 Studies have shown that handicapped people have less education, lower income and fewer are employed than the non-handicapped. 28

The Rehabilitation Act of 1973 defines a handicapped person as one who:

has a physical or mental impairment which substantially limits one or more of such person's life activities. When life activities may include communication, education, mobility, transportation, self-care, adapting to housing, etc., primary attention is given here to those life activities that affect employability. A disabled individual who is likely to experience difficulty in securing, retaining or advancing in employment is considered substantially limited. 29

Jones and Catlin, writers for Progressive Architecture, feel there is a difference between handicapped and the disabled.

A handicapped person is someone who is prevented from attaining his maximum functional level because of environmental constraints, but a disabled person is someone with an impairment of mind or body.

For example, a scientist confined to a wheelchair, working on the sixth floor of a laboratory, could perform as well as a nondisabled

27 Brodsky-Porges, The Cornell H.R.A. Quarterly, p. 6 . 28 Bernie Posner, "Less Than Equal," Disabled U.S.A., May 1978 , p. 14 .

${ }^{29}$ Employment of the Handicapped in State and Local Government (Washington, D.C.: U.S. Government Printing Office, 1979). 
person at his job. If the fire alarm sounds, he becomes handicapped because all the elevators automatically return to the ground floor. His able-bodied companions are able to use fire
stairs. 30

Historically, our society has over-looked the handicapped person. Despite their numbers, they are often hindered by negative public awareness and architectural barriers as by the impediments of others.

Barriers in the community are still reasons why many handicapped individuals cannot lead the full independent lives they would prefer. Legislation can be created to protect the rights of citizens. It can also provide tax dollars for the equalization of opportunities. However, a free society such as ours cannot change people's attitudes through legislation. 31 Therefore, the first barrier to freedom for the handicapped individual is in the minds of ordinary individuals. Few people know very little about the handicapped and fewer have had any contact with them. This is one of the most difficult barriers to tear down, because it is the prejudice rather than the disability that prevents the handicapped citizen from participating fully in life. Therefore, one of the most effective ways of tearing down this barrier is through understanding. 32

${ }^{30}$ Catlin and Jones, Progressive Architecture, p. 66.

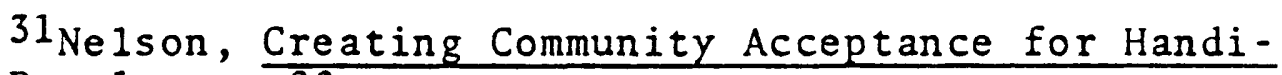
capped People, p. 22 .

32 Report of the Committee on Youth Development (Washington, D.C.: U.S. Government Printing Office, December 1977), p. 21. 
Despite everything that may be done to improve the physical plight of those disabled, many are hampered by improper mental attitudes--not solely their own but also of their families, friends, associates, and society as wel1. 33

Barriers continue to frustrate active disabled people who wish to hold jobs, go to school, shop and lead normal lives. Most handicapped people would agree that a major employment barrier is not their disability. Although thousands of handicapped people have demonstrated unmistakable ability on the job, society regards them as the exceptional.

Keith Russe11, Handicapped American of 1974, writes in the magazine, Performance, "Another reason for eliminating barriers is to get the public used to seeing handicapped people out in the main stream of life. The more we're seen, the better will be our own self opinions." 34

In the field of psychology, it is well known that a person's self image depends greatly on his interaction with others and with the environment. Therefore, a handicapped person's self image is the ability to manipulate within the environment. Because of handicapped people's frustration in attempting to explore the world, they may not try to adapt to it. Then their sense of dependency increases

33 Ernest M. Gutman, A Travel Guide For The Disabled (Springfield: Charles C. Thomas Publishing, 1967), p. vii.

${ }^{34}$ Keith Russe11, "The Handicapped American of the Year," Performance, March 1974. 
and their self-image diminishes. 35

While much as been said and written about other minority groups, little has been publicized about the handicapped. The handicapped are beginning to be seen in a different light now, and the credit for this is directly related to the efforts they have made on their own. These efforts have been made through organizations, protests and lobbying in Washington and at state levels. 36 Much progress has been made in the removal of the barriers. But despite legislation, accessible housing, offices, entertainment, transportation, and other public facilities are still far from the norm.

To integrate disabled people into the mainstream of society, hundreds of organizations for the handicapped are challenging institutions and businesses that do not provide equal opportunity for handicapped citizens. They are demanding that the barriers of environment and attitude be removed and give the handicapped equal access.

The Handicapped Traveler

Restricted physical capabilities do not diminish the intellectual, cultural, and social needs of the handicapped. Handicapped people feel these physical afflictions should not prevent them from an active and aggressive 1 ife.

35 Susan Stephens, "Hidden Barriers," Progressive Architecture, April 1978, p. 94.

36 Morgan, Progressive Architecture, p. 63. 
Therefore, travel by the physically handicapped has been increasing in recent years.

Some industries are opening up the area of travel for the physically handicapped. The airlines encourage the handicapped person to travel and have made their airports accessible to them. Amtrack offers specially fitted seats for the handicapped and bathrooms that accommodate a wheelchair person. In addition, the travel agencies have identified this market and are offering special tours for the handicapped person. 37 Therefore, handicapped people are taking more tours, attending more meetings and traveling has given a more healthy outlook and brought a more interesting 1 ife to the handicapped person. 38

There are innumerable examples of handicapped people traveling and deriving great personal enjoyment from it. Nevertheless, 36 million handicapped men, women and children cope with a world designed for the able-bodied.

Leisure time is considered the nation's number one industry, as measured by people's spending. So it seems ironic that businesses and chambers of commerce are spending so much money on promotion and advertising, but fail to see that barriers preclude them getting business from the physically handicapped. Handicapped persons, physically

37 Lois Reamy, "Meeting the Needs of the Handicapped Traveler," ASTA Travel News, November 1977, p. 84.

38"Accommodate The Handiaapped, Moteletter (Washington: Mote1 Services, Inc., March 1978). 
and financially able to travel, are unrecognized as a responsible, virtually untapped market. 39

Man-made Environmental Barriers

The physical environment has a powerful psychological effect. The environment of architectural barriers affects the development of a person. Robert M. Harris, Ph.D., Director of Psychological Rehabilitative Medicence, Cosa Colina Hospital, Pomona, California--points out that society will not remove these barriers if most people are under the impression that only the handicapped suffer. "Society tends to create a segregated environment for the handicapped, which will effectively give the able-bodied the impression that they have done the right thing by their unfortunate brothers, and also will spare them the sight of crippled people in public facilities. But," he added, "a physical barrier is a barrier for everybody." 40

There appears to be similar agreement among writers that there are two types of barriers preventing the access ibility of the handicapped. These barriers include architectural and psychological.

In relation to Hospitality operations, BrodskyPorges writes in an article for the Cornell H.R.A. Quarterly:

${ }^{39}$ Bruck, Access, p. 15.

40" Where Do We Go From Here," (Washington, D.C.: U.S. Government Printing Office, December 1976). 
It is useless to remove architectural barriers without first eliminating psychological barriers through employee training . . . many hotels and restaurants have put the cart before the horse by proceeding with accessibility modifications before taking the necessary first step: employee attitude modifications. Before you print a Braille menu or widen doorways to admit wheelchairs, you must deal with certain employee attitudes and misconceptions about the physically handicapped or your effort will be undermined. 41

Psychological Barriers

In general, most people feel helpless when confronted by a person with a disability. They experience negative feelings of aversion, repulsion, fear, guilt, anger or pity. But usually there is a willingness on the part of "able people" to help, but a feeling of awkwardness develops when dealing with another's loss of ability. 42

The emotional reaction of many people which generates and perpetuates these attitudes toward disabled people are devastating obstacles to the integration of the handicapped. In order to create a change in this barrier, one writer feels an education and training process is necessary for the community. Through this process people would accept differences and encourage the handicapped to live in the mainstream of life. 43

One writer has classified these feelings about the handicapped into eight categories.

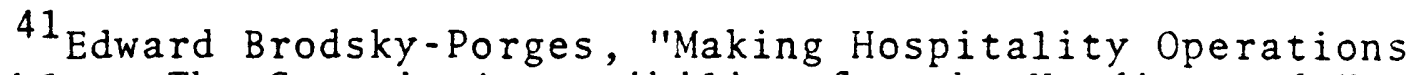
Hospitable: The Step in Accessibility for the Handicapped," The Cornell H.R.A. Quarterly, August 1979, p. 8.

42 Nelson, "Creating Community Acceptance," p. 18. ${ }^{43}$ Ibid., p. 14. 
1. Rejection, with belief that the handicapped should be segregated.

2. Expectation that the disabled have negative emotions.

3. Image of the disabled as useless and dependent.

4. Anticipation of unease during interaction with the disabled.

5. Rejection of close relations with the disabled.

6. Finding persons with cosmetic impairments (assumed controllable) offensive.

7. Anxiety regarding one's own vulnerability.

8. Belief that the disabled deserve special
treatment. 44

This sense of discomfort around the handicapped is a major hurdle employees have to overcome. Educating the employees on the needs of the handicapped and training them in various aspects of serving the disabled guest will make the handicapped feel welcome. Involvement with and continued exposure to handicapped people will change their attitudes. 45

The aim is to make disabilities visible, common and comprehensible to remove the strangeness and the fear the strangeness creates. Once a receptive climate has been created by overcoming attitudinal barrier, attention must be turned to the operational aspects.

Harold Russell feels that it all really comes down to a need for understanding and sensitivity on the part of

${ }^{44}$ Brodsky-Porges, The Cornell H.R.A. Quarterly, p. 8. 45 Ibid., p. 8 . 
the service people. If a person is in a wheelchair or blind, it doesn't affect his capacity to think and feel like anyone else. He says, "It's good business...to make your operation accommodating to all people..."46

\section{Architectural Barriers}

What good are increased opportunities for the handicapped if design barriers prevent them from entering buildings, using public transportation and negotiating city sidewalks? Handicapped people are prevented from integration into the community because architectural barriers impair their ability to move from place to place. ${ }^{47}$

Trying to enter a store in a wheelchair, only to find steps or revolving doors barring entrance, aisles, check-out lanes and fitting room doors too narrow, restrooms inaccessible, public telephones and water fountains out of reach are just a few of the barriers that handicapped individuals face daily. ${ }^{48}$

A handicapped individual describes a situation where he was invited to attend the annual meeting of the President's Committee on Employment of the Handicapped at the Washington Hilton Hotel. He found he was one of 500 or so wheelchair occupants, who were trapped in the barriers of the hotel. He wasn't surprised or stunned

${ }^{46}$ Harold Russe11, "Employing the Handicapped, A Sound Investment," NRA News, September 1978, p. 3.

47 Nelson, Creating Community Acceptance, p. 15. ${ }^{48}$ Bruck, Access, p. 7 . 
because it was par for such meetings. 49

This type of physical environment also has a psychological effect on the individual. These barriers, Dr. Harris writes, "makes disabled people feel dependent, stigmatized, devalued, and degraded." 50

The way in which a building or facility is constructed can greatly affect its usability by the handicapped. The following are standards recommended to the American Hotel and Motel Association by the American National Standards Institute:

1. Ground should be graded, even contrary to existing topography, so that it is level with a primary entrance.

2. Public walkways should be at least $48^{\prime \prime}$ wide, uninterrupted by steps or abrupt changes in level.

3. Where ramps with gradients are necessary, the slope should not exceed a one-foot rise in 12 feet, and the surface should be nonskid.

4. Where a ramp leads to an entrance, there should be a level platform at the top at least five feet square to permit a person in a wheelchair to open the door outward.

5. Doors should have clear openings of no less than 32".

6. Parking spaces should open on one side or be located at the end of a parking lane, allowing room for individuals in wheelchairs to get in and out. Where reserved parking

${ }^{49}$ C.J. Lampos, "Project Nevermore," Performance, 1975 , p. 14 .

50 President's Committee on Employment of the Handicapped, "Where Do We Go From Here," (Washington, D.C.: U.S. Government Printing Office, December 1977). 
spaces for the handicapped are located between conventional parking spaces, they should be $12^{\prime}$ wide and planned so that individuals in wheelchairs are not compelled to wheel behind parked cars.

7. Where curbing surrounds parking lots, access can be made by ramping or beveling the curb at convenient locations.

8. There should not be a difference between the level of a meeting room, dining room, public toilet or other public rooms unless proper ramps are provided.

9. Public toilets should have at least one stall that is three feet wide, preferably five feet deep, has a 32 inch wide door that swings out, handrails on each side mounted $33^{\prime \prime}$ from the floor and a toilet with a seat $20^{\prime \prime}$ high.

10. Elevators should be accessible to the physically handicapped on the level they use to enter the building.

11. Wall-mounted water fountains can serve the handicapped and other guests equally well when the cooler is mounted with the basin 36" from the floor.

12. Conventional public phone booths are not usable by most handicapped individuals, but phone companies can provide other public telephones which are usable by everyone.

13. The layout of rooms intended for the handicap should take into account ease of movement of a wheelchair. There should be telephone accessible from the bed. Mirrors should be placed or tilted so that they reflect a view from the height of a wheelchair. The clothing storage area should be designed so that a person in a wheelchair can store and retrieve clothes easily.

14. The bathroom entrance should be 32 " wide or more. The toilet should be wall-mounted, have one-and-one-half-inch-diameter grab bars on either side. Clear space below a sink will permit access to a wheelchair. All faucet handles should operate easily 
and all hot water lines should be shielded to protect the legs of handicapped guests. Towe 1 racks and other dispensers and disposal units should be no higher than $40^{\prime \prime}$ from the floor. One or more grab bars should be placed around the shower or tub. Showers should have non-skid floor surfaces, and the curbs should be no more than two inches above floor leve1. A shower stool should be provided.51

More hotels are considering the needs of the handicapped in their buildings and renovation. Notable are Holiday Inn and Travel Lodge. Their objectives are one handicapped room per 100 rooms and two such rooms per property. Also programs are underway by Hilton International, Howard Johnson, Ramada Inns, Sheraton, Best Western and other chains. 52

When incorporating complete handicapped facilities in a new property, it adds $8 \%$ to the total construction costs. Renovating an existing property is much more costly. 53 However, in 1977, the Internal Revenue Service (IRS) allowed several new tax incentives permitting lodging, food service and related businesses an allowance of up to $\$ 25,000$ for accessibility modifications. Expenses over $\$ 25,000$ are considered capital expenses. This tax deduction must be claimed as a separate item identified on a timely filed income tax return with documents to substantiate the barrier removal. Also these barrier removals must conform to the

$51_{\text {Hotel }}$ and Motel Management, p. 26.

52 Reamy, ASTA Trave1 News, p. 84.

53 "Industry News, Best Western Showcased at Handicapped Travel Conference," Hoofbeats, January 1978. 
25

standards set by the IRS. 54

Yet today there are many hotels that handicapped people would like to stay in but can't. They are restricted to where they can stay. Therefore, barrier removal is a necessity. Hopefully, there will be legislation aimed at removing these barriers so the physically handicapped person will have the opportunity to travel as other citizens. ${ }^{54}$ Horton and Schechter, Disabled U.S.A. 
CHAPTER I I I

DESIGN OF THE STUDY

The purpose of this study is to test the following Hypothesis: The hotels in the city of Miami Beach, Florida are not meeting the needs of the physically handicapped traveler.

Sample Selection

A questionnaire survey was conducted to test the above mentioned hypothesis. The population used in this study was the hotels located in the city of Miami Beach. The characteristics of this population are homogeneous in nature. In other words, the hotels have a degree of sameness. They are all lodging facilities located in the same geographical area and their facilities and services are available to the public traveler.

The sampling frame of this population was prepared from the Yellow pages of Southern Bell's Telephone book. The frame made up a total of 438 hotels. A sample was drawn from the sampling frame. This sample size was determined by the use of Table 4 , "Size of Sample Necessary To Be Fairly Sure (19 Chances in 20) of Accuracy Within Specified Limits," found in Mildred Parten's book entitled, Surveys, Polls and Samples. 55

55 Mildred Parten, Survey, Polls and Samples (New York: Harper and Brothers, 1950$),$ p. 215. 
By using this table A coefficient confidence level of $95 \%$ is established. This means that the Researcher has a $95 \%$ assurance that only $5 \%$ of the time the results of the sample would not be within the $15 \%$ margin of error. 56

For this study, the $\pm 15 \%$ error with a $50-50$ response are acceptable. This researcher feels a margin of error of $15 \%$ is acceptable because this study is a pioneering effort. Research on the Miami Beach hotels meeting the needs of the handicapped person has not yet been undertaken. The study is exploratory in nature. In addition, the Miami Beach hotels are at the peak of their tourist season and the hotel personnel do not have the time to answer the questionnaire. If the questionnaires are answered, it will probably be done in a hurried fashion.

A 50-50 response is acceptable because this researcher was unaware of the possible answers because of the absence of prior knowledge of studies on this subject.

Identifying the sample is important but difficult. The difficulty arises when determining the sampling procedure. The sample must be representative of the population or the end result of the survey will be distorted. A systematic sampling method was used for selecting the sample of hotels. Systematic sampling is the selection of

56 Herbert Arkin and Raymond R. Cotton, Statistical Methods (New York: Barnes and Noble Books, 1970), p. 149. 
certain hotels according to a predetermined sequence. 57 For example, in this study every 5 th hotel of the frame was selected as a sample hotel. This researcher feels that this method of selecting a segment of the population will provide information of ascertainable reliability.

Collection of the Data

A mail survey questionnaire (Appendix A) was used to collect the data from the drawn sample. There are numerous methods of gathering data, but this researcher found the mail survey to be the most appropriate and applicable for the type of research at hand. Other methods considered by this researcher were phone or face to face interviewing. The major concern was that the hotels are in the middle of their peak season, and it was felt that interviewing was too time consuming. This researcher also felt the mail survey would be less biased in relation to the other methods.

The questionnaire used for this study was closedend and it consisted of two pages. It was designed to be complete, relevant, brief and easy to fill out. The questionnaire obtained information about the facilities of the hotel and the services offered the physically handicapped. To ensure the questions were stated properly, the questionnaire was pretested by the researcher at six hotels in the sample. One general manager, two assistant managers,

${ }^{57}$ Paul D. Leedy, Practical Research, Planning and Design (New York: MacMillan Publishing Co., Inc., 1974), p. 105 . 
and three reservation managers were the respondents of the pretest analysis of the questionnaire. After the pretest, the questionnaire was finalized by the researcher by making some revisions and adding two additional questions.

The questionnaire, cover letter (Appendix B) and a self-addressed stamped envelope were forwarded by mail to the reservation managers of the sample hotels. The reservation manager was selected as the respondent because of his or her knowledge of the hotel's facilities and services. This researcher felt the reservation manager would have more time to fill out the questionnaire. In addition, it was found that during the pretesting of the questionnaire the reservation manager was more cooperative and informative on this subject.

Due to a low rate of response, this researcher found it necessary to personally contact and interview the nonrespondents of the questionnaire.

A second questionnaire (Appendix C) was used in this study. The questionnaire obtained information from handicapped people as to the problems they encountered as a guest in a hotel when traveling. The data gathered from this questicnnaire was used to give this researcher some insight into the problems faced by the handicapped traveler. This questionnaire was not pretested because the information obtained was not used to make any statistical inference. It was used as supportive information in analyzing the findings and preparing a conclusion. 


\section{Data Analysis}

The data collected from the questionnaire was

edited and reviewed by this researcher to ensure accuracy and no ambiguity.

After editing the questionnaire, the data collected was analyzed by this researcher. The questionnaire was analyzed to see whether the hotels are meeting the needs of the physically handicapped traveler. This was accomplished by comparing the responses to the handicapped standards recommended to the American Hotel and Motel Association by the American National Standards Institute. These recommended standards are discussed in Chapter II.

Each category (hotel areas) of the questionnaire was weighted by this researcher in the order of importance to the handicapped guest. For example, Guestroom, Guestroom's Bathroom and Entrance areas were weighted the heaviest with the remaining categories following in importance. After determining the weight of each category, the questions within these categories were weighted as to their importance. The total score for each hotel was calculated. A mean and standard deviation was computed.

Then the recommended standards were weighted by category. An average score of these standards were calculated. This average was considered the mean by this researcher and an assumption was made that one was the standard deviation for the standards. 
Method of Measurement

This study tested the hypothesis by determining the Significance of the Difference Between Two Means. This approach calculated whether the difference was statistically significant or insignificant. From this information the hypothesis was accepted or rejected. The following formula taken from Statistical Methods written by Arkin and Cotton was used to test the hypothesis. 58

$$
\sigma_{D}=\frac{\sqrt{\sigma_{1}^{2}}+\frac{\sigma_{2}^{2}}{N_{1}}}{N_{2}}
$$

The questionnaires were also analyzed to determine what percentage of the hotels were meeting the average recommended standards. This was calculated by comparing the hotels to the categories (hotel areas). This researcher felt that certain areas of the hotels were meeting the needs of the handicapped and other areas were not. Through this comparison, percentages were calculated. This information was used in support of this study.

From these analyses, findings and conclusions were developed in Chapter IV.

${ }^{58}$ Arkin and Cotton, Statistical Methods, p. 152. 
CHAPTER IV

\section{FINDINGS AND DISCUSSION}

Questionnaire Response

A questionnaire (Appendix A), cover letter (Appendix B) and a stamped reply envelope were forwarded to 100 hotels in the city of Miami Beach. Needing a sample size of 43 respondents, (Reference Chapter 3) this researcher had to estimate the number of questionnaires to be sent out. Research shows that the percentage of replies received from mail questionnaires range from 30 to $40 \%$. Forty-three per cent is considered a "very high rate of return." 58 Therefore, 100 questionnaires were sent with an estimated expectancy of $37 \%$ response. These 37 responses in addition to the six pre-tested questionnaires would give a respondent's sample of 43 hotels.

The questionnaires were coded by a number being placed on the stamped reply envelope to distinguish the returns. With this control, follow-up was possible.

This researcher felt 3 weeks was sufficient time to allow for the return of the questionnaires. At the end of the time schedule, only 20 questionnaires were returned, resulting in a response of $20 \%$. These 20 included; 18

${ }^{58}$ Paul L. Erdos, Professional Mail Surveys (New York: McGraw-Hil1 Company, 1970$)$, p. 4. 
completed questionnaires and 2 refusals. This $20 \%$ response ratio is considered low according to researchers.

Due to a low percentage of responses, this researcher found it necessary to follow-up. Due to insufficient time, personal interviews were used as the follow-up method. Twenty-three personal interviews were made by this researcher. The final count of responses was a total of 43 with two refusals.

Problems

This researcher encountered two main problems while collecting data. One problem was insufficient time on the part of the hotel personnel to fill out the questionnaire. During the time of this research, Miami Beach was in the middle of their peak season and the hotel personnel were extremely busy with their guests.

Another problem encountered was the poor attitude reflected by the hotel personnel. One hotel manager abruptly refused to fill out the questionnaire because he didn't want to take the time. Several managers expressed an unconcern for the handicapped market. Many felt extra staff members would have to be added if the hotel did have handicapped guests. One manager felt handicapped people should have their own hotel.

There were cases where the hotel personnel were very interested in this study and the subject matter, and were very cooperative and willing to assist this researcher. 
Other problems such as sampling and non-sampling errors occurred in the statistical area of the study. Sampling errors occurred because:

(a) Low Response Problem. Twenty per cent of all the questionnaires were returned.

(b) Non-response problem: The hotels who could answer the questionnaire if they wanted to but refused to answer.

(c) Sample problem. A sample of the Miami Beach hotels were surveyed rather than the entire population. Using a sample of a population always creates a margin of error.

Non-sampling errors occurred because:

(a) Problem with Coding of Data. Researcher assigning weight to the specific areas of the questionnaire.

(b) Respondent problem. Unwillingness or inability of respondents to provide correct information on the questionnaire.

(c) Processing and Computation. Mechanical errors when recording and coding the obtained information.

Findings

The purpose of this study was to test the following Hypothesis: The hotels in the city of Miami Beach, Florida are not meeting the needs of the physically handicapped traveler. 
The hypothesis was tested by determining the significance of the difference of the means of the Miami Beach hotel sample and the recommended standards. In other words, to prove the hypothesis there had to be significant difference between the hotel mean (4I) and the standard mean (79). This difference could not be merely due to chance. The formula of the Significance of the Difference Between Two Means was used to compute the result.

By using the formula, the difference of the two means was found to be 2.47 . This difference was then multiplied by 3 standard deviations $(2.47 \times 3$ S.D. $=7.4)$ to determine whether this difference was due to chance. Since the actual difference of the mean $(79-41=\underline{34})$ was much larger than the amount (7.41) calculated, it was unlikely that this difference was due merely to chance. Therefore, this statistical test has shown that there was a significant difference between the two means.

The purpose of testing the hypothesis was to aid this researcher in reaching a decision concerning the hotel population by examining the data contained in the sample from the hotels in Miami Beach. This researcher reasonably concluded from the statistical test that the two means were not equal and the hypothesis, the hotels in the city of Miami Beach are not meeting the needs of the physically handicapped, was accepted. 
The questionnaire was also analyzed to determine what percentage of the hotels were meeting the average recommended standards. These percentages were broken down into categories (hotel areas). Listed below are the computed hotel percentages:

Category (Hotel Areas)

\section{Percentage of Hotels}

Guest Room

Guest Room's Bathroom

Entrance

Dining Rooms

Parking Area

Lounge (Bar)

Public Area

Public Area's Bathroom

$71 \%$

$42 \%$

$12 \%$

$76 \%$

$2 \%$

$73 \%$

$78 \%$

$34 \%$

These percentages show that there are four categories that are not meeting the recommended standards. These categories are discussed below.

Bathrooms. The responses on the questionnaire indicate that the main problems are the bathroom doors are not 32 " wide, and the bathrooms themselves are too small for a person in a wheelchair to maneuver around. Also the height of the wash basins, towel dispensers and toilets are not placed at a height usable by someone in a wheelchair. These problem areas are the same ones addressed on the questionnaires filled out by the physically handicapped. Their responses also indicated that more grab rails were needed in bathrooms.

Entrance Area. All the hotels sampled had double doors or doors 32 " wide at their entrance. But $58 \%$ of the hotels had one or more steps leading to this entrance. These steps prevent accessibility by the handicapped person. 
The handicapped responses also discussed this problem. They found that many hotels had to bring them in through the basement or kitchen by using the delivery area ramp for entrance.

Parking Area. The hotel's parking areas were not level with or ramped to the hotel's entrance. Also, the hotels lacked special parking areas for the handicapped. The walkways to the hotels were not $45^{\prime \prime}$ wide or uninterrupted by steps. One handicapped person reflected on his questionnaire how important reserved parking spaces are to him. He uses a walker to get around and walking distances are hard for him. This situation indicates the importance of reserved parking spaces.

Other questions were added to the hotel questionnaire to support this study. It was found:

(a) None of the sampled hotels had parking spaces marked with the International Symbol of Access. The symbol identifies a parking space for a handicapped person.

(b) Only seventeen per cent of the sampled hotels had access for the handicapped peson to their pool or beach area.

(c) One hotel offered a special service to the handicapped. This service was emergency notification to the handicapped guest.

(d) Only 5\% of the hotels offered training classes specifically on the needs and services of the handicapped guest. 
(e) Ten per cent of the hotels had rooms especially designed for the handicapped guest.

The handicapped respondents indicated problems in other areas of the hotel.

(a) The front desk counter is too high for a person in a wheelchair.

(b) The rooms assigned to handicapped guests should be close to the lobby, restaurant and lounge areas.

(c) Braille menus and braille instructions should be placed in the guest's room.

(d) Hote1 lobbies haven't enough room for a handicapped guest with a walker or in a wheelchair to sit in the conversation areas. The coffee tables in front of the sofas prevent walker-users from occuping the sofas.

(e) In the restaurants and lounge areas, the tables are too close together for a walker-user and a person in a wheelchair.

(f) Elevator buttons and public phones are not low enough for the person in a wheelchair.

Conclusions and Recommendations

In view of the findings that the hotels in Miami Beach are not meeting the needs of the handicapped guest, this researcher recommends that professional groups and organizations must become more involved. For instance in the Hospitality Industry, the Hotel and Motel Association should 
devise programs to generate an awareness to the hotels of the problems that the handicapped traveler encounters. They should work together to provide better services for this guest.

Professional groups and organizations need to lobby for federal and state legislation to eliminate architectural barriers so handicapped people can integrate into the mainstream of life. This legislative action will allow individuals with a handicap to live an independent life.

In addition, the hotels need to establish a positive attitude rather than a negative one toward a guest who is handicapped. Attitudes are learned from the results of what one learns from others and from one's own experiences. Therefore, with management demonstrating a negative attitude the employees will reflect the same type of attitude. This attitude must be changed. Employees must be trained to handle the situation of a guest who is handicapped. The best type of training would be first hand experience. Managers should bring in handicapped people to train their employees. Let the employees experience riding in a wheelchair and using a walker around the hotel. Besides learning the needs of the handicapped guest, the employees will also overcome much of their awkwardness of being around a person with a handicap. A future study in this area should be to include management and employee's attitudes toward the handicapped guest. 
The hotels should provide specially designed rooms and special services for the handicapped guest. Special services should include some type of emergency notification, and special features for the blind and deaf guest.

Leisure time, which includes traveling, is such a necessary part of a handicapped person's life. Therefore, it is so very important that the architectural and psychological barriers be eliminated so the handicapped person can be integrated into society.

The Hospitality Industry needs to make these changes to make their facilities accessible to all travelers. They should provide the same opportunities for handicapped people that are available to every other citizen. 


\section{APPENDIX A}

QUESTIONNAI RE

This questionnaire seeks information from the hotel. It is designed to determine the accessibility of a handicapped guest. Place an $X$ in the space that applies to your hotel.

Parking Area

Spaces marked by the International Symbol of Access. - If reserved parking spaces, they should be $12^{\prime}$ wide. Parking spaces should be opened on one side or located at the end of a parking lane.

Public walkways at least $48^{\prime \prime}$ wide, uninterrupted by steps or abrupt changes in level.

Parking area level with Hotel entrance.

Entrance into Hote 1

Ramped curb or beveling the curb from parking area to entrance.

If ramp with gradients, slope should not exceed a one-foot rise in 12 feet and the surface should be non-skid.

If ramp leads to entrance, there should be a level platform at the top at least five square to permit a person in a wheelchair to open the door outward. Entrance door at least $32^{\prime \prime}$ in width.

\section{Inside of Hotel}

\section{Public Area}

Elevators level with lobby.

\footnotetext{
- Elevator buttons low enough for person in wheelchair. Public phone--lowered for wheelchair person.

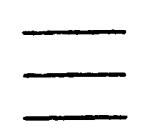
Public drinking fountain--lowered for wheelchair person. Pool, patio and recreation area level with lobby or elevator.

Ramps to the beach area.
} 
Public Bathroom

Level with lobby or elevator.

- Entrance door at least 32 " in width. At least one toilet stall must be $3 \mathrm{Ft}$. wide and 5 Ft. deep with handrails $33^{\prime \prime}$ high.

Wash basins, towel dispensers and toilet must be at a height usable by someone seated in a wheelchair.

Dining Room

Level with lobby or elevator.

- Entrance door at least $32^{\prime \prime}$ in width.

Sufficient seating space for wheelchair.

Tables high enough for person in wheelchair.

Menus in braille.

Lounge Area

Level with lobby or elevator.

Entrance door at least $32^{\prime \prime}$ in width.

Sufficient seating space for wheelchair.

Tables high enough for person in wheelchair.

Menus in braille.

Guest Room

Level with lobby or elevator.

- Entrance door at least $32^{\prime \prime}$ in width. Ample room to maneuver a wheelchair around with ease. Telephone readily accessible from the bed. Mirrors should be placed or tilted so they reflect a view from a height of a wheelchair. Clothing storage area should be designed so that a person can store and retrieve clothes easily.

Guest Room's Bathroom

Level with guest room's floor. Entrance door at least $32^{\prime \prime}$ in width. Ample room to maneuver a wheelchair around. Wash basins, towe 1 dispensers and toilet must be at a height usable by someone seated in a wheelchair. Grab rails around bath tub and toilet. Non-slip tub and shower. Clear space below the sink to permit access to a wheelchair.

If shower, removable shower heads with hose attachments. A shower stool provided. 
Special Services offered

Facilities for housing a seeing eye dog.

- Emergency notification to the handicapped guest, especially the deaf and blind.

Elevator with braille buttons for the blind.

- Door to guest rooms with braille numbers.

Do your employee training classes provide specific training on the needs and services for the handicapped guest.

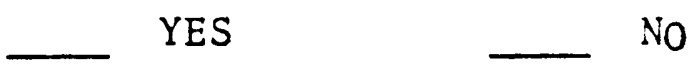

Does your hotel have rooms especially designed for the handicapped guest.

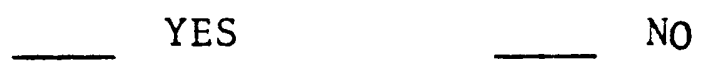

Is your hote 1 


\section{APPENDIX B}

Dear Sir:

Are you aware that approximately 36 million Americans are physically handicapped? These individuals constitute a sizable potential market that has been historically ignored by the lodging business. Today, handicapped people are taking more tours, attending more meetings, and traveling for business. In addition, the handicapped traveler rarely travels alone, making this untapped market a much higher figure. Therefore, hotels need to recognize the physically handicapped traveler as a sizable market for both economic and humanitarian reasons.

In order to increase hotel awareness, I am making a study of the Miami Beach hotels to determine if they are meeting the needs of the physically handicapped. To analyze this situation, I would like to make a survey of your hotel. The information obtained from these questionnaires will be compiled into a Master's thesis that I am presently working on at Florida International University in the School of Hospitality. The source of this information will be kept anonymous.

You and your staff can be of great assistance to me by filling out the enclosed questionnaire and by returning it at your earliest convenience. Your answers to each question are important and valuable. It is most desirous to obtain a complete picture of your facilities in relation to the needs of the handicapped.

This questionnaire can also help you determine whether your hotel is accessible. Perhaps, facility changes are necessary to meet the needs of this untapped market. If physical changes are needed, the Internal Revenue Service allows a tax incentive permitting lodging services an allowance of up to $\$ 25,000$ for accessibility modifications. To get a copy of this regulation, you can write: Office of the Chief Counsel, Internal Revenue Service, Washington, D.C. 20224 .

I will be anxiously awaiting your answers to the enclosed questionnaire. Thank you.

Sincerely, 


\section{APPENDIX C}

\section{QUESTIONNAIRE}

This questionnaire seeks information from the physically handicapped citizen who has traveled. It is designed to help determine the needs of a handicapped hotel guest. please comment on each question.

1. What is your specific handicap?

2. Do you travel?

3. When traveling, do you travel with a companion or alone?

4. How many hotels have you been a guest in during the last 5 years?

5. Have you experienced problems as a handicapped person when staying in these hotels?

6. What kind of problems, if any, were experienced in these areas of the hotel?

Parking Lot

Hotel Entrance

Lobby and other Public areas

Front Desk

Guest Room

Bathroom

Restaurant

Lounge

Elevators

Swimming and other Recreation areas 
7. What was the attitude of the hotel staff and were they responsive to your special needs?

8. Have you observed any changes in the hotel facilities or staff's attitude in relation to meeting the needs of the physically handicapped guest during your travels?

9. Would you travel more often if the hotels had better facilities for the handicapped guest?

10. What are your recommendations to the hotel manager in the areas discussed? 


\section{B IBLIOGRAPHY}

"Accommodate The Handicapped." Moteletter. Washington: Motel Services, Inc. March 1978.

Action, Norman. "Global Dimensions of Disability." Disabled U.S.A., August 1979.

"American National Standards Institute Specifications." Washington, D.C.: U.S. Government Publication, 1974 .

Arkin, Herbert and Cotton, Raymond R. Statistical Methods. New York: Barnes and Noble Books, 1970

Atwater, Maxine. "Visiting Chicago." Disabled U.S.A., June 1979.

Best, Gary A. The Sociology of Physical Disability and Rehabilitation. St. Louis: C.V. Mosley Company, 1978.

Brodsky-Porges, Edward. "Making Hospitality Operations Hospitable: The Step in Accessibility for the Handicapped." The Cornell H.R.A. Quarterly, August 1979.

Brodsky-Porges, Edward. "We 1 coming The Handicapped Traveler." The Cornell H.R.A. Quarterly, November 1978 .

Bruck, Lilly, Access. New York: Random House, 1978.

Catlin, John H. and Jones, Michael A. "Design for Access." Progressive Architecture, April 1978.

Clifton, Andrew and McLean, Barbara, editors. Mealtime For Severely and Profoundly Handicapped Persons. Baltimore: University Park Press, 1977.

Cox, Keith K. and Enis, Ben M. The Marketing Research Process. Pacific Palisades: Goodyear Publishing Co., Inc., 1972 . 
"Employment of the Handicapped in State and Local Government." Washington, D.C.: U.S. Government Printing Office, 1979 .

Erdos, Paul L. Professional Mail Surveys. New York: McGraw-Hill Company, 1970 .

Gilfoyle, Roger. "The Handicapped and the Hotel Bath." Interiors, November 1978 .

Green, Paul E. and Tull, Donald S. Research For Marketing Decisions. New Jersey: Prentice-Hall Inc., 1978.

Gutman, Ernest M. A Travel Guide For The Disabled. Springfield: Charles C. Thomas Publishing, 1967.

Horton, Muriel and Scheehter, Deborah. "Tax Incentives for Business Women and Men." Disabled U.S.A., Vol. 1 , No. 7,1978 .

"Hotels and Motels and the Handicapped." Hotel and Motel Management, January 1973.

Hoye, Pamela. "Teaching Others About Disability." Disabled U.S.A., Volume 2, No. 2, 1978.

"Industry News, Best Western Showcased at Handicapped Trave 1 Conference." Hoffbeats, January 1978.

Lampos, C.J. "Project Nevermore." Performance, 1975.

Leedy, Paul D. Practical Research Planning and Design. New York: MacMillan Publishing Co., Inc., 1969.

Lund, Laurel and Van Zante, Shirley. "Barrier-Free Rooms for the Disabled." Better Homes and Gardens, March 1979.

Morton, David. "Bearing Down on Barriers." Progressive Architecture, April 1978.

Nelson, John G. Wheelchair Vagabond. Santa Monica: Project Press, 1977 .

Nelson, Roberta. Creating Community Acceptance For Handi capped People. Springfield: Bannerstone House, 1978 .

"News Report." Progressive Architecture, April 1978.

Parten, Mildred. Survey, Polls and Samples. New York: Harper and Brothers, 1950, p. 215. 
Posner, Bernie. "Less Than Equal." Disabled U.S.A.,

President's Committee for Employment of the Handicapped. "Where Do We Go From Here." Washington, D.C.: U.S. Government Printing Office, December 1976.

Reamy, Lois. "Meeting the Needs of the Handicapped Traveler." ASTA Travel News, November 1977.

Report of the Committee on Youth Development. Washington, D.C.: U.S. Government Printing Office, December

Ruffner, Robert H. "An Architect Tells How." Performance, June 1973.

Russe11, Harold. "Employing the Handicapped, A Sound Investment." NRA News, September 1978.

Russe11, Harold. "The Window." Disabled U.S.A., Vo1. 1, No. 1, 1976.

Russe11, Keith. "The Handicapped American of the Year." Performance, March 1974 .

Sale, Dick. "Thinking of Others: Attitudes Towards Disabled People." Performance, February 1975.

Stephens, Susan. "Hidden Barriers." Progressive Architecture, April 1978.

"Travel Tips For The Handicapped." Consumer Guide to Travel Information, 1978.

Weiss, Louise. Access To The World: A Travel Guide for 1977.

Wallace, Marcia. "Ready for the Handicapped." Travel and Leisure, April 1978. 


\section{VITA}

Judith Casey was born in Hays, Kansas on May 31, 1944. Her elementary and high school education was received within the Code11 School System, Code11, Kansas. In 1966, she received a Bachelor of Science in Home Economics from Fort Hays Kansas State University, Hays, Kansas. From the years 1966 to 1970, she taught Home Economics in high schools within the Kansas school system. The next two years (1970-72) were spent working as a Home Economist for the Western Power and Electric Company in Dodge City, Kansas.

In August 1972, she entered the United States Army as a First Lieutenant in the Adjutant General Corps. Her first assignment was as an Assistant Adjutant at the Military Police School in Fort Gordon, Georgia. In 1974, she was reassigned to the San Francisco District Recruiting Command as the Adjutant. During her assignment in San Francisco she was promoted to Captain. In 1977 , she was reassigned to Taegue, Korea as the Commander of the 117 th A.G. Detachment. In 1978, she was selected for Graduate School at Florida Inernational University, and in March 1980, she successfully completed a Master's of Science Degree in Hospitality Management. 